\title{
ANURIA ASCRIBED TO ACUTE TUBULAR NECROSIS IN INFANCY AND EARLY CHILDHOOD
}

\author{
BY \\ I. J. CARRÉ and J. R. SQUIRE \\ From the Children's Hospital, Birmingham, and the Department of Experimental Pathology, University of Birmingham
}

(RECEIVED FOR PUBLICATION JUNE 29, 1956)

The improved prognosis of acute renal failure has largely resulted from the use of conservative dietary régimes of treatment as suggested by Borst (1948), Pratt (1948) and Bull, Joekes and Lowe (1949, 1950). Few publications refer to children with acute tubular necrosis treated in this manner. In 1948 Pratt reported seven children with acute anuria of over 24 hours $^{*}$ duration treated conservatively with a limited fluid and liberal glucose diet: five recovered. Children with acute tubular necrosis successfully treated on similar lines have also been reported by Riddell (1951, two patients). Kaplan and Fomon (1953, one patient) and Wagner (1954, one patient).

Other recent reports of acute tubular necrosis in children have been concerned primarily with the biochemical and pathological aspects (Zuelzer, Charles. Kurnetz, Newton and Fallon, 1951 : Schwartz, Tomsovic and Schwartz, 1951).

The purpose of this paper is to direct attention to the condition of acute tubular necrosis in infancy and early childhood, to describe problems encountered in the management of three patients under 6 years of age and to discuss the biochemical disturbances observed. Possible aetiological factors are considered. The results include a review of each of these children two years or more after their initial illness.

\section{Case Reports}

Case 1. P.B., a girl aged 5 years 2 months was admitted at 3.50 a.m. on December 25, 1952, with a 24-hour history of dyspnoea and epigastric pain. She appeared an ill child with a temperature of $102 \cdot 8^{\circ}$ : signs of pneumonic consolidation were present over the left chest. Three-hourly intramuscular injections of crystalline penicillin were started immediately. Twelve hours later her condition had deteriorated. As additional therapy she was given $100 \mathrm{mg}$. aureomycin intravenously at 6.30 and again the following morning.

The urine output was not recorded on the day of admission but she passed urine twice, the last occasion at 4.30 p.m. She vomited five times during the day. The blood pressure was $105 / 75 \mathrm{~mm}$. Hg. The following day intravenous fluid therapy was begun because of vomiting and dehydration. Varying proportions of the following three solutions were given: normal saline, $5^{\circ}$ o dextrose in $1 / 5$ isotonic saline, and $5^{\circ} \mathrm{o}$ dextrose solution. No urine was passed. Antibiotic therapy was confined to penicillin.

Next day she appeared improved and the fever had subsided. Abdominal distension and absent bowel sounds were noted. The blood pressure was $115 / 80 \mathrm{~mm}$. Hg. Vomiting persisted and intravenous fluids were continued. By evening the sacral region and ankles were slightly oedematous. No calculus or renal calcification was demonstrated radiologically. One millilitre of urine was obtained on catheterization: this contained numerous red and white blood cells but no casts or crystals. Culture was sterile. On December 28 pulmonary oedema had developed and both ankle and sacral oedema had increased. She remained anuric. Intravenous fluids were discontinued (a total of $2,800 \mathrm{ml}$. having been given in $\mathbf{4 8}$ hours, equivalent in salt content to 1 litre of isotonic saline). Bull's régime was substituted. She remained anuric until January 2, 1953, i.e., eight days. During the period of anuria vomiting decreased, oedema subsided, no hypertension was recorded and abdominal distension with absent bowel sounds persisted: she was at times mentally confused. Spectroscopic examination of the serum was negative. Infection of the mouth with Candida albicans was noted on December 31. A purpuric eruption on the neck appeared on January 1 : no abnormalities were found in the bleeding, clotting or prothrombin times and the platelet count was 160,000 per c.mm.

Serum biochemical findings are shown in Fig. 1. An E.C.G. on January 1 (serum potassium concentration 8.5 mEq./litre) showed sharply peaked $T$ waves in lead II and chest leads. In an attempt to lower the serum potassium, $5 \mathrm{~g}$. of cation-exchange resin, 'zeocarb $225^{\circ}$ in the hydrogen form, was given through the gartric tube. In addition, vomit, with a potassium content of $3.9 \mathrm{mEq}$./litre, was replaced via the gastric drip by an equal quantity of an artificial mixture containing equivalent salt concentrations except for potassium, i.e., $30 \mathrm{ml}$. N/10 HCl, $30 \mathrm{ml}$. $\mathrm{N} / 10 \mathrm{NaCl}$ and $40 \mathrm{ml}$. water. At 9.0 a.m. the following morning (January 2) bowel sounds were audible on auscultation: the serum potassium had fallen by $2.2 \mathrm{mEq}$./litre. Twelve hours later $40 \mathrm{ml}$. of urine were passed. After four days the urine 
output had increased to 1 litre/24 hours. (To obtain an accurate assessment urine was collected by indwelling catheter.) The fluid intake for each 12 hours was determined as the theoretical insensible loss for the period plus a quantity of half-strength isotonic saline equal to the previous 12 hours' urine output. Additional potassium was given from January 5 .

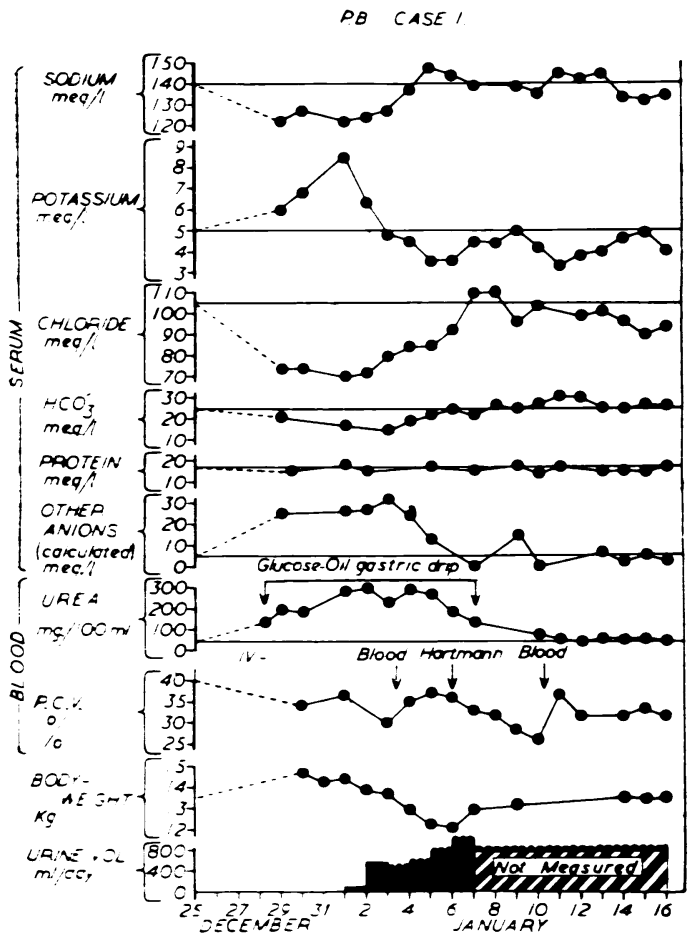

Fig. 1.-Results of serum and blood analyses, weight records and urine output during the period of anuria and early diuresis (Case 1). (Incomplete urine collections are represented by blocks with serrated upper margins.)

The patient appeared improved the day after the onset of diuresis but at 1 a.m. on the succeeding day (January 4) she suddenly collapsed, became unconscious, cold and grey. Her blood pressure was unrecordable. She recovered spontaneously and half an hour later her blood pressure was $90 / 70 \mathrm{~mm}$. $\mathrm{Hg}$. The serum concentrations of potassium and sodium during this episode were $4.6 \mathrm{mEq}$./litre and $137 \mathrm{mEq}$./litre. A further fall in blood pressure but without associated constitutional disturbance was recorded at 9 a.m. the same day. Two hours later the blood pressure was $110 / 75 \mathrm{~mm}$. $\mathrm{Hg}$. No similar episodes were noted subsequently. A blood transfusion of $250 \mathrm{ml}$. was given later that day because of a fall in haemoglobin to $10.6 \mathrm{~g} . / 100 \mathrm{ml}$.

Attempts to give additional oral fluid and electrolytes to offset urine losses caused increased vomiting. The resulting dehydration was corrected with intravenous fluid and electrolytes given over a period of 24 hours starting on January 6. Her subsequent progress was complicated by a urinary infection with Candida aibicans. (This aspect of her illness will be reported separately.) She was last reviewed when aged 8 years and 3 months, i.e., three years after her illness. She had had no illnesses and was an apparently healthy child. Her only symptoms were frequency of micturition and nocturnal enuresis due to a contracted bladder possibly resulting from the urinary infection. An intravenous pyelogram two months after her illness was normal. She was small (weight $21.8 \mathrm{~kg}$. and height $115.6 \mathrm{~cm}$., averages for age $25 \cdot 2 \mathrm{~kg}$. and $125 \mathrm{~cm}$.). There were no other abnormal clinical findings. Her blood pressure was $100 / 05 \mathrm{~mm}$. $\mathrm{Hg}$. The urine contained no albumin and showed no abnormality on microscopy: there was no aminoaciduria. The P.C.V. was $37^{\circ}{ }_{0}$ and the blood urea $46 \mathrm{mg}$. $/ 100 \mathrm{ml}$.

The results of endogenous creatinine clearances at varying stages of the illness and subsequently are listed below:

\begin{tabular}{|c|c|c|c|}
\hline \multirow[b]{2}{*}{ Date } & \multirow{2}{*}{$\begin{array}{l}\text { Interval } \\
\text { after } \\
\text { Onset of } \\
\text { Diuresis }\end{array}$} & \multicolumn{2}{|c|}{ Creatinine Clearance } \\
\hline & & (ml. min.) & $\begin{array}{l}\text { ml. min. } 1.73 \text { sq.m. } \\
\text { Surface Area }\end{array}$ \\
\hline $\begin{array}{r}5.1 .53 \\
4.2 .53 \\
18.3 .53 \\
27.1 .54 \\
27.1 .56\end{array}$ & $\begin{array}{l}3 \text { days } \\
5 \text { weeks } \\
11 \text { weeks } \\
13 \text { months } \\
37 \text { months }\end{array}$ & $\begin{array}{r}4 \cdot 0 \\
15 \cdot 2 \\
23 \cdot 4 \\
25 \cdot 6 \\
47\end{array}$ & $\begin{array}{r}11 \\
40 \\
62 \\
63 \\
102\end{array}$ \\
\hline
\end{tabular}

Case 2. R.J., a boy of 7 months, was admitted on the evening of August 18, 1953. Except for infantile eczema his progress had been satisfactory until August 12 when he developed a "cold" and seemed troubled by 'teething'. He remained unwell and two days later "sulphatriad" (sulphathiazole, sulphadiazine and sulphamerazine) $0.5 \mathrm{~g}$. six-hourly was prescribed but, due to vomiting, was discontinued after only five doses had been given. Sulphonamides had not been previously prescribed for either internal or external administration. No urine was passed after August 14 until August 17 when 'a little urine' was passed, the first for three days. During this period vomiting, anorexia and irritability persisted. He was admitted to another hospital where on catheterization only a few drops of urine were obtained. He was transferred to the Children's Hospital next evening (August 18). On examination he appeared a healthy infant, and weighed $8 \cdot 2 \mathrm{~kg}$. The only abnormal clinical findings were a temperature of $99 \cdot 6^{\circ}$ and a blood pressure of $180 / 115 \mathrm{~mm}$. $\mathrm{Hg}$. Limited quantities of $5 \%$ glucose solution were given.

The following day (August 19) anuria persisted and Bull's régime was instituted: daily requirements were assessed as $200 \mathrm{ml}$. fluid and 800 calories. Intramuscular injections every fifth day of streptomycin (100 mg.) and crystalline penicillin $(50,000$ units) were prescribed. Biochemical findings are shown in Fig. 2. No calculus or renal calcification was demonstrated radiologically. During the next few days his general condition remained good but restlessness required control with intramuscular 
paraldehyde. His blood pressure rose to a maximum of $190 / 130 \mathrm{~mm}$. $\mathrm{Hg}$ on August 20 .

The serum potassium concentration at 10 a.m. on August 21 was $7.7 \mathrm{mEq}$./litre, a fall of $0.8 \mathrm{mEq}$./litre in 24 hours: an E.C.G. showed no abnormality. At 2.30 p.m. the same day he passed urine, after virtually seven days' complete anuria. Only $378 \mathrm{ml}$. urine were passed during the ensuing three days, after which a

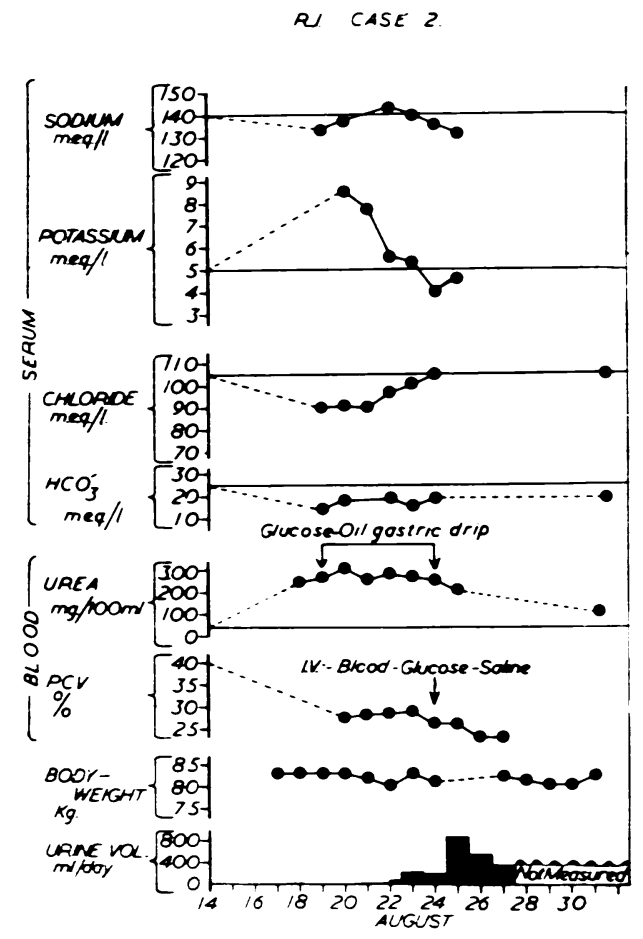

Fig. 2.-Results of serum and blood analyses, weight records and urine output during the period of anuria and early diuresis (Case 2).

satisfactory output was maintained. The glucose-fat mixture was replaced by milk feeds on August 24 and the dose of streptomycin and penicillin increased to $350 \mathrm{mg}$. and 500,000 units daily respectively. Increasing the oral fluid and electrolyte intake caused a recurrence of vomiting, which resulted in negative fluid balance and dehydration; additional fluids and electrolytes were given intravenously and by nightly intragastric drip from August 24-26. By August 28 he was taking a normal diet and all fluid requirements by mouth. Further progress was complicated by a urinary infection. The pyrexia, present from the time of admission to hospital, rose to $102 \cdot 4^{\prime}$ on August 29 . Urine specimens contained many pus cells, and Pseudomonas pyocyanea was consistently grown in pure culture. (Unfortunately urine before August 29 was not cultured.) The urinary infection was cured with intramuscular polymixin $B$ given in $7 \mathrm{mg}$. doses eight-hourly for eight days. A blood transfusion of $200 \mathrm{ml}$. was given because of a progressive fall in haemoglobin to $7 \cdot 2 \mathrm{~g} . / 100 \mathrm{ml}$. A month later the child was well and apyrexial: the urine showed no abnormalities on microscopy or culture and no renal abnormality was detected by subcutaneous pyelogram or extraperitoneal pneumography.

Eight months later he was well apart from a recurrence of infantile eczema. His blood pressure was $115 / 80 \mathrm{~mm}$. $\mathrm{Hg}$ and weight $10.7 \mathrm{~kg}$. A urine specimen showed no abnormality. Serum electrolytes were within the normal range but blood urea was $49 \cdot 3 \mathrm{mg}$. $/ 100 \mathrm{ml}$. He was last reviewed aged 3 years and 2 months, i.e., two years and five months after his illness. He had remained well except for an attack of 'bronchitis' which had been treated with penicillin. He weighed $16.6 \mathrm{~kg}$. and was $95 \frac{1}{4} \mathrm{~cm}$. in height (averages for age, $15 \mathrm{~kg}$. and $96 \mathrm{~cm}$.). There were no abnormal physical signs. Eczematous lesions had cleared. The blood pressure was $90 / 55 \mathrm{~mm}$. $\mathrm{Hg}$. The urine showed no abnormality; there was no aminoaciduria. The P.C.V. was $4^{\circ}$ o and the blood urea $50 \mathrm{mg} .100 \mathrm{ml}$. The endogenous creatinine clearance was $26.5 \mathrm{ml}$. $/ \mathrm{min}$., equivalent to $70 \mathrm{ml} . / \mathrm{min} / 1.73 \mathrm{sq} . \mathrm{m}$. surface area.

Case 3. H.G., a girl of 8 months, was admitted on the evening of December 10, 1953. Her progress had been satisfactory until December 8 when she awoke from her afternoon sleep crying as if in pain. She was thought to have otitis media and was given an injection of 1,000,000 units crystalline penicillin. One and a half hours later she vomited, collapsed and appeared shocked. She recovered spontaneously from this episode but for the remainder of the day was miserable, reluctant to take feeds and was stated to have passed urine frequently and in excessive quantities.

Next day she remained unwell and a second injection of $1,000,000$ units of crystalline penicillin was given at 2 p.m. This was followed within half an hour by the appearance of a generalized non-urticarial erythematous rash which persisted for one hour. There was no associated constitutional disturbance. She had never been given penicillin before but her mother, when four months pregnant, had had injections of penicillin for maxillary sinusitis.

The child was last known to have passed urine at 7.30 a.m. on December 9 . During this day she remained peevish and irritable: she vomited that evening and throughout the night. The following day she was still unwell although vomiting had subsided. No urine was passed. She was admitted to hospital the same evening. On examination she appeared a healthy baby weighing $8 \cdot 3 \mathrm{~kg}$. A faint erythematous rash was present cn both arms. There were no other abnormal physical findings. Her food and fluid intake was restricted to $5^{\circ}$ glucose solution.

Vomiting ceased next day, December 11, but anuria persisted. The blood pressure was 115/?. No radioopaque calculus was demonstrable in the urinary tract. The haemoglobin was $11 \mathrm{~g} . / 100 \mathrm{ml}$. and the serum penicillin level (48 hours after the last penicillin injection) 
was 0.25 units $/ \mathrm{ml}$. Biochemical findings are shown in Fig. 3.

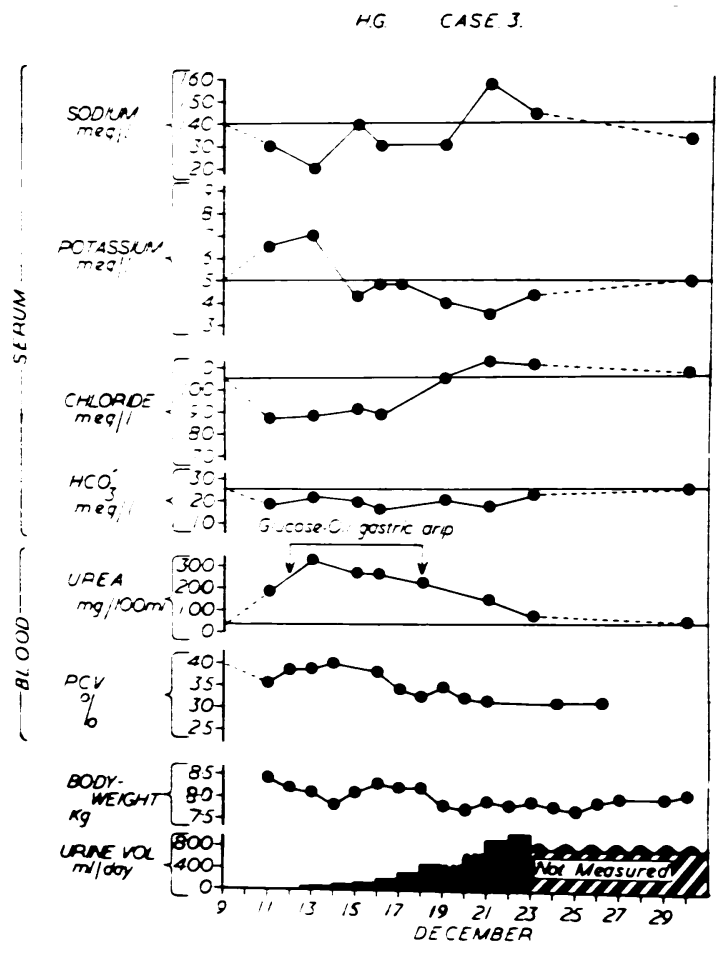

FIG. 3.-Results of serum and blood analyses, weight records and urine output during the period of anuria and early diuresis (Case 3). (Incomplete urine collections are represented by blocks with serrated upper margins.)

Bull's régime was instituted: $200 \mathrm{ml}$. fluid and 800 900 calories per 24 hours were prescribed. Catheterization was not performed and no antibiotics were given.

She remained anuric until December 13 when $40 \mathrm{ml}$. urine were passed: an E.C.G. (serum potassium $7 \mathrm{mEq}$. (litre) demonstrated no abnormality. Only $43 \mathrm{ml}$. of urine were passed during the next 24 hours. Oliguria persisted with an average of $160 \mathrm{ml} .24$ hours until December 18 when a good output was established for the first time since the onset of urinary suppression nine days previously. Throughout the baby remained well without pyrexia or hypertension. An accentuation of the anaemia, first apparent six days previously, was recorded on December 17.

Between December 19 and 23 the daily urine output increased to approximately 1 litre 24 hours. Fluid, electrolyte and calorie requirements were supplied as milk and $5^{\circ}$, glucose with added sodium and potassium chloride. Vomiting became troublesome, but was controlled with promethazine 8-chlorotheophyllinate ('avomine'), $6 \mathrm{mg}$. twice daily; additional fluids were given by slow intragastric drip at night, and in this way an adequate fluid intake was maintained. From December 23 the baby made an uninterrupted recovery.

This child was last reviewed when aged 2 years 10 months i.e., two years two months after her illness. She had remained well except for another attack of otitis media, on this occasion treated with tetracycline. She weighed $12.3 \mathrm{~kg}$. and her height was $90.2 \mathrm{~cm}$. (averages for age, $13.7 \mathrm{~kg}$. and $91.9 \mathrm{~cm}$.). There were no abnormal physical findings. The blood pressure was $10060 \mathrm{~mm}$. $\mathrm{Hg}$. Urine contained no albumin and no abnormal microscopic deposit. There was no aminoaciduria. The P.C.V. was $38 \cdot 5^{\circ}$ o and blood urea level $37 \mathrm{mg}$. $100 \mathrm{ml}$. The endogenous creatinine clearance was $49 \mathrm{ml}$. min., equivalent to $154 \mathrm{ml}$. $\min .1 \cdot 73$ sq. $\mathrm{m}$. surface area.

\section{MANAGEMENT}

The following scheme applied to all three patients. apart from modifications described in individual case reports. Each child was weighed daily and the haematocrit estimated. Accurate fluid intake and output balances were summated for either 12- or 24-hour periods. Biochemical analyses of blood and, during diuresis, of urine were made daily where necessary. A conservative dietary régime was employed using a high-calorie, high-carbohydrate, protein- and electrolyte-free diet with restricted fluids as advocated by Bull et al. (1949). The daily caloric requirements for the children were calculated on the basis of 100 calories $/ \mathrm{kg}$./day and for the 5-year-old child of 75 calories/ $\mathbf{k g}$./day. These were supplied using a mixture of peanut oil and glucose in the proportion of 1 to 4 with acacia to emulsify in a volume of water calculated as necessary to replace the daily insensible losses of fluid. The latter were assessed on a theoretical insensible fluid loss under basal condition of $1 \mathrm{~g}$. $/ \mathrm{kg}$./hour for infants (Levine, Kelly and Wilson, 1930), 0.8 g. $/ \mathrm{kg}$./ hour for children aged 6 to 9 years (Ginandes and Topper, 1936) and $0.5 \mathrm{~g} . / \mathrm{kg}$./hour (Benedict and Root, 1926: Miles, 1929) for children over 10 years of age. Vitamin supplements were added to the mixture which was administered by continuous intragastric drip. All vomit was collected into cellophane funnel-shaped receivers, strained and returned into the gastric drip.

With the onset of diuresis increased oral fluids containing sodium, chloride and later potassium were given as required. These amounts were assessed on the basis of $(a)$ body-weight, $(b)$ urine volumes and $(c)$ serum biochemistry. On occasion. modifications were introduced in the light of clinical findings and urine analyses. Intravenous fluids. including blood, were only used when specially indicated.

Antibiotics were given in Cases 1 and 2, as described in the case reports. 


\section{DISCUSSION}

In the patients described, a period of acute urinary suppression with nitrogen retention (anuric phase) was succeeded by a diuresis resulting in a steadily falling blood urea, and uncontrolled losses of water and electrolytes (diuretic phase). All three patients recovered with no serious renal impairment demonstrable on review at least two years later. This sequence of events is characteristic of acute tubular necrosis.

\section{Anuric Phase}

Calorie Administration. In our patients both diet and method of administration were well tolerated. Vomiting tended to diminish once treatment had been established. Loose stools in Case 2 may have been caused by the high fat content of the diet.

The need to give such a high-calorie, oil-containing diet as used in these patients has been questioned. For example, Stock (1952) has recommended for adult patients a diet limited to $100 \mathrm{~g}$. carbohydrate a day. The arguments advanced in favour of this therapy, in addition to its being less nauseating, have mainly been founded on observations by Gamble (1947) that the protein-sparing effect of carbohydrate is not appreciably increased by amounts in excess of $100 \mathrm{~g}$. daily. These conclusions, based on investigations of healthy persons, are not, in Bull's opinion (1955), necessarily applicable to ill patients with renal failure. He emphasizes, moreover, the value of a high-carbohydrate diet in retaining potassium within the cells, an effect of considerable importance in the management of these patients. For these reasons Bull (1955), while no longer recommending a high-fat diet as essential, advocates at least $300 \mathrm{~g}$. carbohydrate daily for adult patients with acute renal failure.

Fluid Requirements. In Table 1 variations in weight are compared with food and water intake and urine output for each patient. Extrarenal water losses have been calculated from these using the formula

Extrarenal water loss $=($ body weight loss $)-($ weight of food and water intake) - (weight of urine)

Possible weight loss from starvation has been disregarded in view of the high calorie intake and short periods covered by these calculations. During the period under review Case 2 had an elevated temperature and some loose stools; no intestinal loss occurred in Case 1. The average environmental temperature of Cases 2 and 3 was $70^{\circ}$ and $68^{\circ}$ : no readings were recorded for Case 1.

The fluid requirements of these children were calculated on the basis of physiological insensible losses occurring under basal conditions. In each case these estimates proved grossly inadequate and approximated to only half the observed extrarenal losses (Table 1). Recently Heeley and Talbot (1955) have reported similar observations on 39 children living in hospital under non-basal conditions. These authors also concluded that it was only possible to predict within broad limits the rate of insensible fluid loss in individual patients. The dangers of overhydration during the anuric phase are well recognized. However, a state of underhydration is equally undesirable. Such a condition enhances renal insufficiency and increases cellular catabolism (Black, McCance and Young, 1944), an effect directly opposed to the aims of treatment.

The daily recorded weights of these children provided an invaluable guide to the state of hydration. (Haematocrit readings, however, proved a poor index owing to the development of anaemia.) Bull (1955) has suggested that it may be advisable when treating anuric patients to aim at a gradual weight loss. He has reasoned that because water is released from fat catabolism an alteration in the ratio of dry weight to total weight with concomitant cellular and extracellular overhydration will result

TABLE 1

CALCULATIONS OF EXTRARENAL WATER LOSSES DURING ANURIC AND EARLY DIURETIC PERIODS

\begin{tabular}{|c|c|c|c|c|c|c|c|}
\hline \multirow{2}{*}{$\begin{array}{l}\text { Case } \\
\text { No. }\end{array}$} & \multirow{2}{*}{$\begin{array}{l}\text { Period of } \\
\text { Observation }\end{array}$} & \multirow{2}{*}{$\begin{array}{l}\text { Weight } \\
\text { Loss } \\
\text { (g.) }\end{array}$} & \multirow{2}{*}{$\begin{array}{c}\text { Weight of } \\
\text { Food and } \\
\text { Water Intake } \\
\text { (g.) }\end{array}$} & \multirow{2}{*}{$\begin{array}{c}\text { Weight } \\
\text { of Urine } \\
\text { (g.) }\end{array}$} & \multicolumn{2}{|c|}{ Extrarenal Water Loss* } & \multirow{2}{*}{$\begin{array}{c}\text { Estimated Basal } \\
\text { Insensible Water } \\
\text { Loss } \\
\text { (g. kg. body wt. hr.) }\end{array}$} \\
\hline & & & & & $\begin{array}{c}\text { Daily Average } \\
\text { (g.) }\end{array}$ & $\begin{array}{l}\text { (g. /kg. body } \\
\text { wt. } / \text { hr.) }\end{array}$ & \\
\hline 1 & $30.12 .52-3.1 .53$ & 1.140 & 1,340 & 350 & 532 & $1 \cdot 6$ & $0 \cdot 8$ \\
\hline 2 & $\left\{\begin{array}{l}18.8 .53-21.8 .53 \\
21.8 .53-24.8 .53\end{array}\right.$ & $\begin{array}{l}57 \\
29\end{array}$ & $\begin{array}{l}1,250 \\
1.780\end{array}$ & $\begin{array}{r}0 \\
359\end{array}$ & $\begin{array}{l}436 \\
483\end{array}$ & $\begin{array}{l}2 \cdot 3 \\
2 \cdot 5\end{array}$ & $\begin{array}{l}1 \cdot 0 \\
1 \cdot 0\end{array}$ \\
\hline 3 & $\left\{\begin{array}{l}11.12 .53-14.12 .53 \\
14.12 .53-17.12 .53\end{array}\right.$ & $\begin{array}{c}570 \\
370 \\
\text { (gain) }\end{array}$ & $\frac{1.252}{2.323}$ & $\begin{array}{r}84 \\
482\end{array}$ & $\begin{array}{l}579 \\
490\end{array}$ & $\begin{array}{l}2 \cdot 9 \\
2 \cdot 5\end{array}$ & $\begin{array}{l}1 \cdot 0 \\
1 \cdot 0\end{array}$ \\
\hline
\end{tabular}

- Calculated from formula shown at top of page and dividing by number of days in period of observation. i.e., three except in Case 1 which was four. 
if the body weight is kept constant. Theoretically, given a calorie intake sufficient to balance energy expenditure, a constant body weight, as aimed at in our cases, should not imply overhydration.

Clinical Findings. Relatively few clinical disturbances were observed. All three patients vomited. The elder child (Case 1) was mentally disorientated during the late stages of the anuric phase while R.J. (Case 2 ) was unduly restless during this period.

In Case 1 absent bowel sounds with abdominal distension and absolute constipation were noted throughout the anuric phase. The return of towel sounds coincided with a fall in serum potassium of $2.2 \mathrm{mEq}$./litre and heralded the onset of diuresis by 12 hours. Similar findings were not observed in the other patients.

A purpuric eruption developed on the seventh day of anuria in Case 1. No abnormality of the blood clotting or bleeding times, prothrombin time or total platelet count was demonstrated.

The infant R.J. (Case 2) was the only patient with pyrexia during this phase. As discussed later this may have been related to urinary infection.

Hypertension was recorded in one patient only (Case 2); a maximum blood pressure of 190/130 mm. $\mathrm{Hg}$ was recorded during the anuric phase. His hypertension had subsided to $150 / 100 \mathrm{~mm}$. $\mathrm{Hg}$ on the sixth day of diuresis and to $115 / 85 \mathrm{~mm}$. $\mathrm{Hg}$ five months later; a blood pressure reading when last reviewed at $3 \frac{1}{2}$ years of age was $90 / 55 \mathrm{~mm}$. $\mathrm{Hg}$. The renal tract infection which this child developed may have been partly responsible for delaying the fall in blood pressure to physiological levels. Swann and Merrill (1953) reported both a raised systolic and diastolic pressure in about one-quarter of their adult patients during the period of urinary suppression.

Anaemia. The anaemia noted in all three children was normocytic and of such rapid onset as to make red cell destruction the likely mechanism.

Only in Case 3 was the anaemia neither treated by blood transfusion nor influenced by the development of a urinary infection. In this child the major fall in haemoglobin occurred during the first week of diuresis. A similar observation has been reported by Strauss (1948) and Swann and Merrill (1953). It is possible that in our patient the anaemia had developed some days previously but its degree had then remained unrecognized because of a concomitant reduction in plasma volume. No response to oral iron was noted after two weeks treatment.
Serum Biochemistry. Biochemical results for blood and serum are shown in Figs. 1, 2 and 3. The rate of increase in blood urea during the early part of the anuric phase and before the institution of a high-calorie diet varied from about $40 \mathrm{mg}$./ $100 \mathrm{ml}$. (Case 1) to $70 \mathrm{mg}$./ $100 \mathrm{ml}$. (Case 3) per day. The protein-sparing effect of the glucose-oil mixture, as mirrored by the rate of rise in blood urea, could not be assessed in Cases 2 and 3 as both these patients passed urine within 48 hours of starting this treatment. In Case 1 the rate of increase appeared to fall from $42 \mathrm{mg}$. $/ 100 \mathrm{ml}$. to $27 \mathrm{mg}$./ $100 \mathrm{ml}$. per day. These figures agree with those of Bull et al. (1949) in adults.

The plasma bicarbonate level was reduced in all three patients. No corrective measures were adopted. Retention of organic acid, sulphate, and phosphate radicals is probably largely responsible for the acidosis of acute renal failure. This is supported by evidence from Case 1. In this child anions, other than $\mathrm{Cl}^{\circ}, \mathrm{HCO}_{3}{ }^{\circ}$ and protein (calculated by substracting the sum of these anions from the sum of the cations, $\mathrm{Na}^{-}-\mathrm{K}^{-}$), totalled $25 \mathrm{mEq}$./litre or approximately three times the physiological value.

Low serum sodium and chloride and high potassium concentrations were recorded in these patients during the anuric phase. As will be noted later, an electrolyte shift between the intra- and extra-cellular compartments may have accounted for some of these changes. In two patients (Cases 1 and 2) the serum potassium rose to $8.5 \mathrm{mEq}$./litre. Measures, additional to the high carbohydrate diet designed to reduce the serum potassium concentration, were adopted in Case 1 only and included the use of ion exchange resins. Urine was passed within 24 hours of instituting these measures and no assessment of their efficacy could be made. A number of workers (Elkinton, Clark, Squires, Bluemle and Crosley, 1950; Evans, Jones, Milne and Yellowlees, 1953) have reported on the effectiveness of ion exchange resins in lowering the serum potassium concentration.

\section{Diuretic Phase}

Urine Volume. It is customary to divide the diuretic phase into an early period, in which the urine output remains relatively restricted, and a late diuretic period. The early diuretic period in these patients has been arbitrarily defined as the period during which the urine output remained less than $20 \mathrm{ml} . / \mathrm{kg}$./day. This period was of variable duration, i.e., one, three and four days, and was not of comparable length to the anuric phase. 
TABLE 2

RESULTS OF EXAMINATION OF FIRST URINE SPECIMEN PASSED AFTER ANURIC PHASE

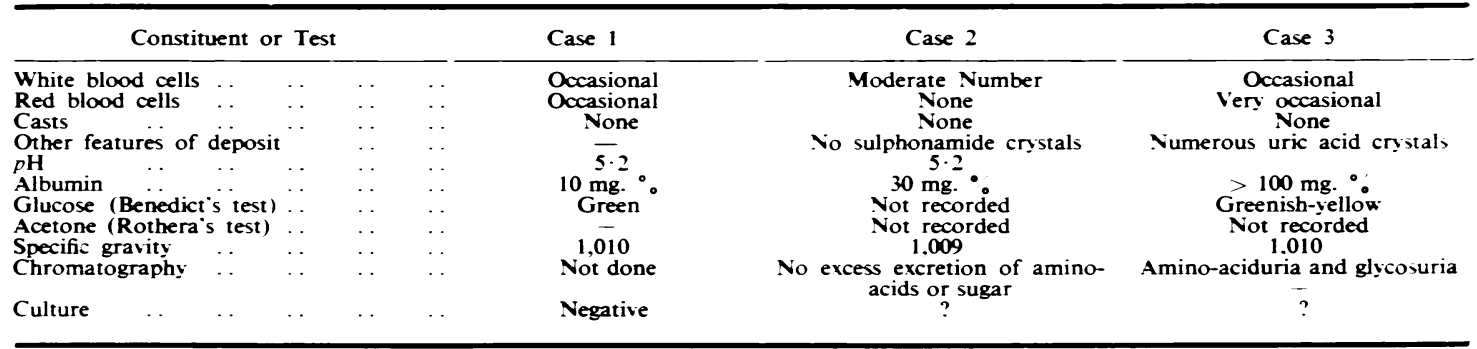

Examination of First Urine Specimen Passed after Anuric Phase. The findings are listed in Table 2 . These are substantially in agreement with previously recorded observations in adults.

Albuminuria was maximal in Case 3. This gradually subsided and two weeks after the onset of diuresis could no longer be detected.

Glycosuria was found in two patients (Cases 1 and 3) and amino-aciduria in Case 3. The aminoacids excreted in excess by the latter patient were cystine, valine, leucine and isoleucine, aspartic acid, lysine and glutamic acid. Chromatographic studies two days later showed the same abnormalities but of lesser degree. No further urine specimens were examined until two years later; no amino-aciduria was then found. Similar observations of glycosuria and amino-aciduria have been reported by Lowe, Moodie and Thomson (1954) and Emslie-Smith, Johnstone, Thomson and Lowe (1956). From investigations of six adult patients with acute tubular necrosis, these workers concluded that both abnormalities reflected proximal tubular damage.

Blood and Urine Urea Concentrations. During the first week of diuresis the rate of fall in blood urea was similar for each patient, namely 27,22 and $24 \mathrm{mg}$./100 ml./day in Cases 1,2 and 3 respectively; the fall appeared to be uninfluenced when protein was added to the diet. The average urine urea concentration during this period was $720 \mathrm{mg} . / 100 \mathrm{ml}$. and $1,260 \mathrm{mg}$. $/ 100 \mathrm{ml}$. in Cases 2 and 3 ; concentrations only two to seven times that of the blood were recorded. Urine urea was not estimated in Case 1.

Comparison of Serum Concentrations of $\mathrm{Na}^{-}$, $\mathrm{Cl}^{\prime}$ and $\mathrm{K}^{-}$with Urine Losses. In Fig. 4 serum concentrations of these ions have been compared with balance data. With efficient tubular function low serum $\mathrm{Na}^{-}, \mathrm{Cl}^{-}$and $\mathrm{K}^{-}$concentrations result in a greatly reduced urinary loss of these ions; in our patients the urine losses were abnormally high in relation to low serum values, implying impaired tubular function. For example, in relation to low serum concentrations high urine losses of $\mathrm{Na}^{-}$and $\mathrm{Cl}^{-}$were recorded in Case 1 during the first three days of diuresis and of $\mathrm{Na}^{-}$in Case 2 on the fourth and fifth days. During the fourth and fifth days of diuresis in Case 1 and the eighth, ninth and tenth days in Case 3 , relatively large potassium losses occurred despite serum concentrations of $4 \mathrm{mEq}$./ litre or less.

Evidence of impaired renal conservation of $\mathrm{Na}$, $\mathrm{Cl}^{\circ}$ and $\mathrm{K}^{-}$was less evident in Case 2 and no amino-aciduria or glycosuria was recorded, suggesting that tubular involvement may have been less extensive in this patient. This would also imply that the severity of tubular impairment is not directly related to the duration of anuria which in Case 2 lasted seven days compared with four days in Case 3.

That the ability of the kidneys to conserve individual ions does not return at the same rate for all substances is illustrated by the data relating to Case 1. Appreciable conservation of sodium and chloride is evident on the fourth and fifth days of diuresis while potassium losses remain relatively uncontrolled for at least three more days (Fig. 4). The charts of Case 3 show similar features.

Acid-Base Balance. Acidosis was recorded in these patients. The urinary $p \mathrm{H}$ although reduced was not as low as would be .produced by a normally functioning kidney in response to similar degrees of acidosis. The urinary $p \mathrm{H}$ in Case 1 , for example, varied between $5 \cdot 2$ and $5 \cdot 6$ in association with a serum $\mathrm{CO}_{2}$-combining power of 17 and $15 \mathrm{mEq}$./litre.

Similarly there was evidence suggesting an impaired production of ammonia. In Case 1 urinary ammonia excretion during the first three days of diuresis was $0.25 \mathrm{mEq} . / \mathrm{kg}$./day and in Case 2 only $0.01 \mathrm{mEq} . / \mathrm{kg}$./day. The urinary ammonia was not estimated in Case 3. 
Trends in Extracellular Fluid Volume and Extrato Intra-cellular Fluid Shifts. It was possible to make approximate estimates of chloride balances from intakes and urinary losses as shown in Fig. 4, since extrarenal losses of chloride were probably small. Changes in total body chlorides could therefore be calculated. Assuming that chloride does not pass into cells and that its extracellular concentration is proportional to that of the serum, volume changes in extracellular fluid were deduced with the following results.

The extracellular fluid volume was constant to within $7^{\circ}$ in Case 2 between August 19 and 24 . In Case 1 , there appeared to be an expansion of about $5^{\circ}$ ond $10^{\circ}$ o on the first and third days of diuresis compared with the later period of anuria; this was followed by a contraction which was corrected by infusion of Hartmann's solution. In Case 3, calculations also suggested an expanding extracellular fluid volume during the first week of diuresis, especially the first four days. In Cases 1 and 3, therefore, the extracellular fluid volume at the end of anuria may have been below the physiological level.

Assuming that the changes in extracellular fluid volume have been correctly estimated by this procedure, the total sodium and potassium content of the extracellular fluids can be calculated and compared with the amounts retained or lost as estimated by the balance studies. In every case, potassium retained during the diuretic phase was greatly in excess of any change in the extracellular fluid content, indicating that potassium had passed into the cells. These cellular gains amounted to about $20 \mathrm{mEq}$. in one day in Case 1 , and $70 \mathrm{mEq}$. in six days in Case 3 . In corresponding periods, the cells appeared to have lost sodium into the extracellular fluid, the amounts being calculated as
$60 \mathrm{mEq}$. in Case 1 and $110 \mathrm{mEq}$. in Case 3. It was also possible in Case 1 to make approximate estimates of these ionic transfers for the anuric period; there was apparently appreciably more sodium in the cells at the end of anuria than there

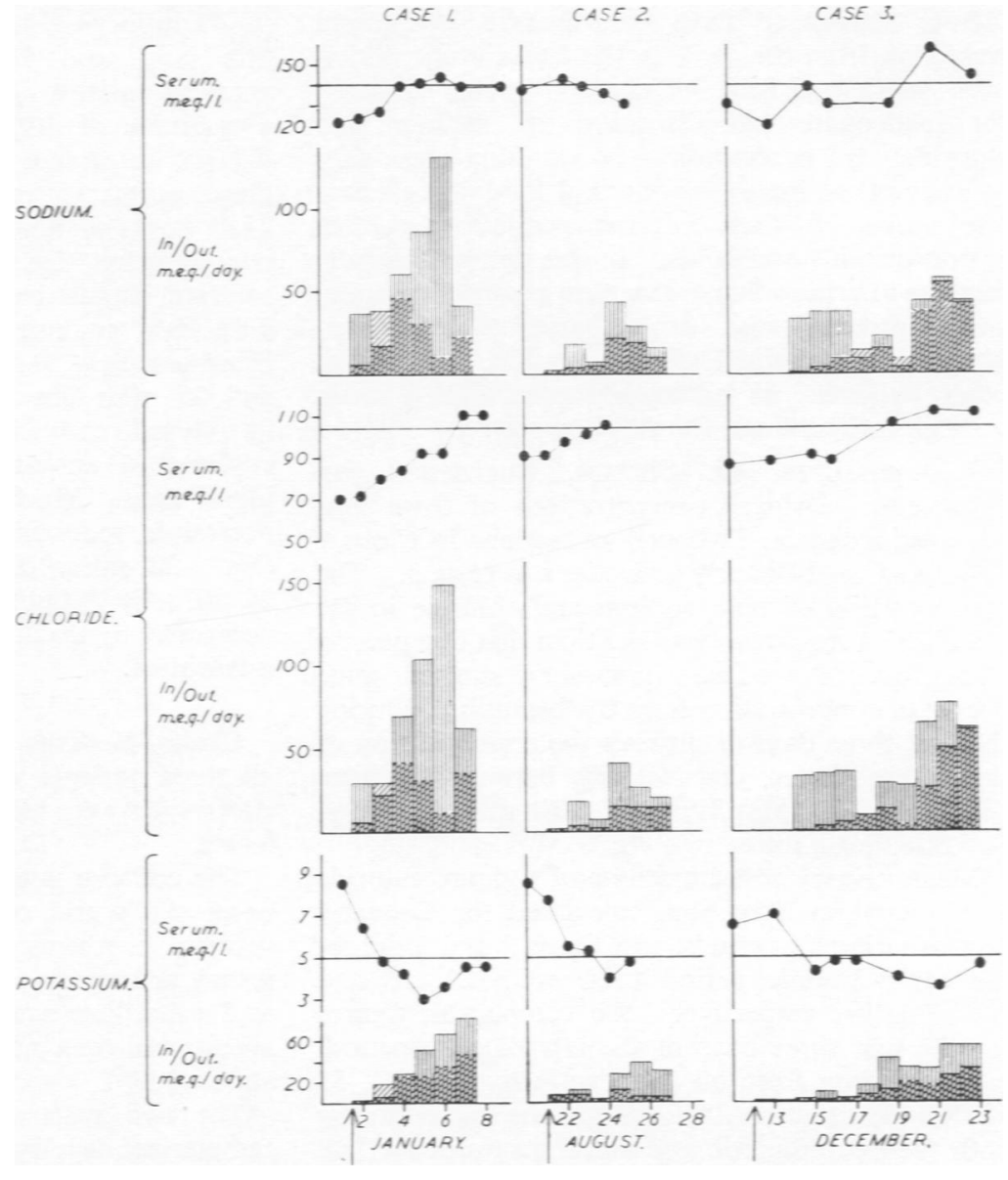

Fig. 4.-Balance data for sodium, potassium and chloride compared with serum concentrations. Arrow indicates onset of diuresis.

Vertically hatched blocks $=24$-hour intake.

Diagonally hatched blocks $=24$-hour urinary output.

(Where upper margin of block is represented by interrupted line this indicates that, for calculation of output, urine volumes have been assessed from changes in body weight, after allowing for extrarenal losses and fluid intakes of water.)

was after six days of diuresis when normal serum electrolyte concentrations had been restored. It is now well known that such transfers are liable to occur in periods of metabolic upset, such as acidosis. Their occurrence, however, needs to be considered together with the possibility of changes in extracellular fluid volume when planning the quantity of electrolytes to be given during the diuretic stage. 
Management. Our régime was as follows:

MaINTENANCE of Hydration. Although we were aware of the likelihood of dehydration developing during this period, two patients (Cases 1 and 2) became dehydrated and required resuscitation with intravenous saline fluids. In retrospect, three main factors appear to have contributed: (a) Rapid transition from the early to the late diuretic period with sudden sixfold increases in urine output; (b) inadequate administration of sodium and chloride; (c) accentuation of vomiting secondary to attempts at increasing the oral fluid and electrolyte intake. In Case 3 it was possible to control hydration with oral fluids. In this patient the daily increase in urine volume was more gradual; vomiting was controlled with promethazine 8-chlorotheophyllinate ('avomine') which was not given to the other patients. In addition supplementary fluids were given by intragastric drip at night.

Requirements of Sodium, Chloride and Potassium. Urinary concentrations of these ions were estimated on 12-hourly collections in Cases 1 and 2 and on 24-hourly collections in Case 3. The concentration of both sodium and chloride in the initial urine specimens was less than that of a plasma ultrafiltrate; the urinary potassium showed some degree of concentration from the beginning. During the first three days of diuresis the concentration of these ions varied considerably between patients, i.e., $\mathrm{Na}^{-}$9-70 mEq./litre, $\mathrm{Cl}^{\prime}$ 3-64 mEq./litre and $\mathrm{K}-21-83 \mathrm{mEq}$./litre.

Mean urinary concentrations of sodium, chloride and potassium have been calculated for the early and late diuretic periods. In Cases 2 and 3 during the early diuretic period these were 22,16 and $34 \mathrm{mEq}$./litre respectively; the comparable figures for the first three days of the late diuretic period, based on data from all three patients, were 41,35 and $25 \mathrm{mEq}$./litre. The mean urine losses during both the early diuretic and initial stages of the late diuretic periods approximated to 30,25 and $30 \mathrm{mEq}$. of $\mathrm{Na}^{-}, \mathrm{Cl}^{-}$and $\mathrm{K}^{-}$per litre of urine.

Balance data (Fig. 4) illustrate that in order to maintain physiologically normal serum concentrations it was necessary to give sodium, chloride and potassium in amounts greatly in excess of urine losses. Shifts between intra- and extra-cellular compartments, deficiencies occurring during the anuric period and intestinal losses probably accounted for these additional requirements. Accepting these children as representative cases, the sodium, chloride and potassium requirements during the initial stages of diuresis may be conservatively assessed as between one and a half times and twice the urine losses, i.e., approximately 50 ,
40 and $50 \mathrm{mEq}$. of $\mathrm{Na}^{-}, \mathrm{Cl}^{-}$and $\mathrm{K}^{-}$per litre of urine voided. In view of the acidosis, limited renal production of ammonia and maximally acid urine, it would seem rational to give alkali to these patients. A stock solution containing 0.35 g. $\%$ potassium chloride and $0.45 \mathrm{~g}$. ${ }^{\circ}$ sodium bicarbonate ( $\equiv 47 \mathrm{mEq}$./litre $\mathrm{K}^{-}$, $47 \mathrm{mEq}$./litre Cl', $54 \mathrm{mEq}$./ litre $\mathrm{Na}^{-}$and $54 \mathrm{mEq}$./litre $\left.\mathrm{HCO}_{3}{ }^{\prime}\right)$ given in amounts equal to the urine output and diluted with a quantity of $10 \%$ glucose solution sufficient to balance extrarenal losses of water would provide these estimated requirements. During the first 24-48 hours of diuresis or until the serum potassium concentration has fallen to near normal, this solution should be substituted by one containing $0.15 \mathrm{~g} .{ }^{\circ}$ o sodium chloride and $0.2 \mathrm{~g} .{ }^{\circ}$ sodium bicarbonate ( $\equiv 50 \mathrm{mEq}$./litre $\mathrm{Na}^{-}, 25 \mathrm{mEq}$./litre $\mathrm{Cl}^{\prime}$ and $25 \mathrm{mEq}$./litre $\left.\mathrm{HCO}_{3}{ }^{\prime}\right)$. A milk diet can be introduced early in the diuretic phase on the evidence of an established diuresis and a falling blood urea. Much of the sodium, chloride and potassium requirements will be provided by milk $\left(\mathrm{Na}^{-} 22 \mathrm{mEq}\right.$./litre, $\mathrm{K}^{-} 41 \mathrm{mEq}$./litre and $\mathrm{Cl}^{\prime}$ $28 \mathrm{mEq}$./litre) but additional supplements may be necessary if renal conservation is not fully reestablished.

Clinical Features. Increased vomiting occurred in all three patients when additional oral fluids and electrolytes were given to balance increasing urinary losses.

The collapse noted in Case 1, 28 hours after the onset of diuresis, could not be correlated with any specific biochemical disturbance; although the serum potassium concentration fell in this patient to $3 \mathrm{mEq}$./litre two days later, no clinical disturbances were then noted and an E.C.G. showed no abnormality.

The two patients (Cases 1 and 2) who were catheterized developed urinary infections. In Case 1 an indwelling catheter was used. In this child the urine became infected with Candida albicans; this organism had been recovered some days previously from patches of oral thrush presumed to have developed in association with antibiotic treatment. In Case 2, Pseudomonas pyocyanea was grown in pure culture from urine passed on the seventh day of diuresis. This finding was confirmed subsequently on several occasions. Unfortunately, of previous urine samples none were cultured and only the first specimen passed after the anuric phase was examined microscopically, an excess of white blood cells being reported. This was the only child to have a pyrexia during the anuric and early diuretic phases. It is probable that the urinary infection 
had been present several days before its discovery and had followed catheterization on the third day of anuria. This contention is supported by the unusual infecting organism and absence in a male child of any demonstrable renal abnormality on subsequent investigation. These observations would indicate that catheterization of this type of patient should be avoided if possible. Accurate urine collections can be obtained, as in Cases 2 and 3, with apparatus similar to that used for metabolic studies (e.g., Blainey, 1956).

\section{Aetiology}

The reason for the development of acute renal failure in these patients must, on the available evidence, be largely speculative.

The three children had an infection at the onset of renal failure, namely pneumonia, coryza and otitis media; only in Case 1 was the infection severe.

The onset of anuria did not coincide with a state of shock. Vomiting with secondary clinical dehydration was a probable contributary factor in Case 1. In the other two children vomiting was less troublesome and dehydration was not evident in the early stages.

In all three patients the onset of anuria coincided with the giving of antibiotics or chemotherapy. It is probable that the urinary suppression in Case 2 was related to 'sulphatriad" medication. That sulphonamides may cause oliguria or anuria is well authenticated. In some instances this may result from tubular and ureteric obstruction by sulphonamide crystallization; in others hypersensitivity has been invoked as explanation. The latter hypothesis would appear to apply to our patient. This infant, who had infantile eczema, had been given only 2.5 g. 'sulphatriad' (sulphathiazole, sulphadiazine and sulphamerazine), part of which had been vomited. The first urine passed after the anuric phase $(p \mathrm{H} \mathrm{5 \cdot 2)}$ contained no excess of red blood cells and no sulphonamide crystals.

An abnormal response to penicillin was evident in Case 3. Vomiting and collapse followed by a period of polyuria occurred one and a half hours after an injection of crystalline penicillin : a generalized erythematous rash appeared half an hour after a second injection given 24 hours later. Urinary suppression developed about 18 hours after the first injection. On the basis of these observations it is considered that the penicillin was at least a contributory factor in the development of renal failure. Only one reference (Merrill, 1955) has been found citing acute tubular necrosis as a complication of penicillin therapy, although various adverse reactions, mostly of a hypersensitive nature, have been reported (Batchelor, Horne and Rogerson, 1951 ; Kern and Wimberley, 1953; Mayer, Mosko, Schutz, Osterman, Steen and Baker, 1953).

That the intravenous aureomycin was in any way an aetiological factor in Case 1 rests entirely on the timing of events. The incrimination of this antibiotic must therefore be very tentative, especially as pneumonia, for which the child received this treatment, is mentioned by Darmady (1952) as a cause of acute tubular necrosis.

None of the children had previously received similar therapy. The mother of the infant H.G. (Case 3), however, had been given penicillin injections during the fourth month of her pregnancy. No evidence was obtained of allergic manifestations in these patients or their relatives, except for infantile eczema in Case 2.

\section{Prognosis}

There are no published long-term follow-up reports of children recovering from acute tubular necrosis and few reports of adults. Lowe (1952) reported on a follow-up of 14 adult patients seen between one month and three years after their initial illness. He concluded that a favourable prognosis could be given once recovery from the acute episode had occurred. However, renal function, although adequate, tended to remain below the lower limit of normal. Similar observations were recorded by Finkenstaedt, O'Meara, Weller and Merrill (1953).

Our three patients have been reviewed two and three years after their illness. All three have remained in good health. Two (Cases 1 and 3) are below average weight and height for age. None have a hypertension. Endogenous creatinine clearances are considered to be within normal limits in Cases 1 and 3, and only somewhat reduced in Case 2. Cases 1 and 2 have a slightly raised blood urea. The significance of these minor abnormalities is difficult to assess. A firm prognosis can only be based on long-term follow-up of more children, but so far as our studies go, a good prognosis can be offered.

\section{SLMMARY}

Three cases are described of acute tubular necrosis with anuria of four to eight days ${ }^{\circ}$ duration. These patients, two babies and a 5-year old child, recovered. The results of a review of these children two to three years later are given.

The treatment, which was conservative, is outlined and the difficulties encountered discussed. Extrarenal fluid losses have been calculated and serve as a guide to the fluid requirements of similarly affected children. They proved to be about double 
currently accepted figures for basal insensible losses under physiological conditions.

Possible aetiological factors are discussed ; penicillin is regarded as having been a contributory factor in one patient.

Clinical, haematological and urinary disturbances are noted and their significance and prevention discussed.

Results of biochemical determinations on the blood are recorded; these are related to biochemical determinations on the urine and balance data for sodium, chloride and potassium for the early stages of diuresis. Treatment is considered in relation to these observations. Estimates of extra- to intracellular ionic shifts and extra-cellular fluid volume changes are computed.

Our thanks are due to Drs. W. C. Smallwood and W. H. P. Cant for permission to publish these cases, Dr. H. Bickel for the chromatographic studies, Dr. J. D. Blainey for advice in the treatment of these patients and preparation of this paper, Miss E. M. Hickmans, Mr. H. B. Salt and the staff of the Biochemical Department for the biochemical data, the ward sisters and nursing staff for their invaluable assistance and Mr. R. A. Crockson for the diagrams.

\section{REFERENCES}

Batchelor, R. C. L., Horne, G. O. and Rogerson, H. L. (1951).
Benedict, F. G. and Root, H. F. (1926). Arch. intern. Med., 38, 1. Black, D. A. K., McCance, R. A. and Young, W. F. (1944). J. Physiol. (Lond.), 102, 406.

Blainey, J. D. (1956). Lancet, 1, 138.

Borst, J. G. G. (1948). Ibid., 1, 824.

Bull, G. M. (1955). Ibid., 1, 731 and 777.

- Joekes, A. M. and Lowe, K. G. (1949). Ibid., 2, 229.

- - , (1950). Clin. Sci., 9, 379

Darmady, E. M. (1952). Proc. roy. Soc. Med., 45, 844. Crosley, A. P. (1950). Amer. J. med. Sci., 220, 547.

Emslie-Smith, D., Johnstone, J. H., Thomson, Margaret B. and Lowe, K. G. (1956). Clin. Sci., 15, 171.

Evans, B. M., Jones, N. C. Hughes, Milne, M. D. and Yellowlees, H. (1953). Lancet, 2, 791 .

Finkenstaedt, J. T., O'Meara, M. P., Weller, J. M. and Merrill, J. P. (1953). J. clin. Invest., 32, 567.

Gamble, J. L. (1947). Harvey Lect. (1946-47), 42, 247.

Ginandes, G. J. and Topper, A. (1936). Amer. J. Dis. Child., 52, 1335

Heeley, A. M. and Talbot, N. B. (1955). Ibid., 90, 251

Kaplan, S. A. and Fomon, S. J. (1953). Ibid., 85, 633.

Kern, R. A. and Wimberley, N. A. Jr. (1953). Amer. J. med. Sci., 226, 357.

Levine, S. Z., Kelly, Margaret and Wilson, J. R. (1930). Amer. J. Dis. Child., 39, 917.

Lowe, K. G. (1952). Lancet, 1, 1086

Moodie, G. and Thomson, Margaret B. (1954). Clin. Sci., 13, 187.

Mayer, P. S., Mosko, M. M., Schutz, P. J., Osterman, F. A., Steen, L. H. and Baker, L. A. (1953). J. Amer. med. Ass., 151, 351 .

Merrill, J. P. (1955). The Treatment of Renal Failure. New York.

Miles, W. R. (1929). Proc. Soc. exp. Biol. (N.Y.), 26, 577.

Pratt, E. L. (1948). Amer. J. Dis. Child., 76, 14.

Riddell, H. I. (1951). J. Urol. (Baltimore), 65, 513.

Schwartz, R., Tomsovic, E. J. and Schwartz, I. L. (1951). Pediatrics, 7, 516.

Stock, R. J. (1952). Bull. N.Y. Acad. Med., 28, 507.

Strauss, M. B. (1948). New Engl. J. Med., 239, 693.

Swann, R. C. and Merrill, J. P. (1953). Medicine (Baltimore), 32, 215 .

Wagner, Joan (1954). Gt Ormond Str. J., 4 (no. 7), 66.

Zuelzer, W. W., Charles, S., Kurnetz, R., Newton, W. A. and Fallon R. (195i). Amer. J. Dis. Child., 81, 1 . 